\title{
THERMOPHYSICAL PROPERTIES OF THE PEQUI PULP IN DIFFERENT CONCENTRATIONS
}

\author{
PROPRIEDADES TERMOFÍSICAS DA POLPA DE PEQUI EM DIFERENTES \\ CONCENTRAÇÕES
}

\author{
Elisabete Piancó de SOUSA ${ }^{1}$; Alexandre José de Melo QUEIROZ ${ }^{2}$; \\ Rossana Maria Feitosa de FIGUEIRÊDO² ${ }^{2}$ Joyce Edja Aguiar dos SANTOS $^{3}$; \\ Danielle Martins LEMOS ${ }^{4}$
}

1. Doutoranda em Engenharia Agrícola pela Universidade Federal de Campina Grande - UFCG, Campina Grande, PB, Brasil. elisabete_pianco@yahoo.com.br; 2. Professor Titular da Unidade Acadêmica de Engenharia Agrícola - UFCG, Campina Grande, PB, Brasil; 3. Mestranda em Engenharia Agrícola pela UFCG, Campina Grande, PB, Brasil; 4. Doutoranda em Engenharia Agrícola pela UFCG, Campina Grande, PB, Brasil.

\begin{abstract}
The pequi fruit (Caryocar coriaceum Wittm) has a great economic interest, regarding the use of its fruits in cooking as a source of vitamins and extraction of oils for the manufacture of cosmetics. However, are unknown studies on the thermophysical properties (specific heat, thermal diffusivity and thermal conductivity), in which properties are very important to the pulp being favored in an industrial level. The work in question was aimed at studying the physical properties of the pequi pulp with levels of total soluble solids of $6,8,10$ and $12{ }^{\circ}$ Brix. The physical properties were studied: specific heat, thermal diffusivity and thermal conductivity. The specific heat of the pulps was determined using the method of mixtures, the thermal diffusivity was determined using the method proposed by Dickerson and the thermal conductivity KD-2 equipment. Therefore, it was found that the specific heat tended to increase with the increase of temperature and total soluble solids content of the pulp. The thermal diffusivity of the pequi pulp decreased with the increase in total soluble solids; the thermal conductivity of the pulp did not show a definite increase in temperature trend in the pulps investigated.
\end{abstract}

KEYWORDS: Caryocar coriaceum Wittm. Specific heat. Thermal conductivity. Thermal diffusivity.

\section{INTRODUCTION}

The presence of native species with economic potential fruitful in the Cerrado region deserves special attention; among them is the pequizeiro, much for its high occurrence such as the sensory and nutritional characteristics of its fruit, which contribute to the supply of the nutritional requirements of the population (GONÇALVES et al., 2011; SOUZA et al., 2007).

Pequi is a cariocacea that can be found evenly distributed throughout the Southeast, West and Northeast of Brazil, representing the main source of income for the population. In recent years, the fruit gained nutritional and economic importance and its trade has expanded beyond the borders of Brazil, being exported to other countries, including Australia (ALVES et al., 2010).

In Brazil, the increased demand for food products brings some consequences, such as requiring modernization, technological adaptation and better quality for industries. In food processing it is necessary to know the physical properties for calculations of processes, which may be subjected. (MOURA et al., 2005). However, to obtain pulps intended for manufacturing thermal treatments are indispensable, such as heating and cooling, the same used to inactivate the enzymes and slow the metabolic and microbiological processes (ARAÚJO et al., 2004).

Therefore, it becomes inevitable the knowledge of thermophysical properties, such as specific heat, thermal conductivity and thermal diffusivity, which for pequi pulp (Caryocar coriaceum Wittm) are still unknown studies on the thermophysical properties, which are of great importance so that the pulp is benefited for industrial level. Therefore, this work aimed to study thermophysical properties of the pequi pulp in different concentrations of total soluble solids $(6,8$, 10 and $12^{\circ}$ Brix).

\section{MATERIAL AND METHODS}

The raw material used was pequi (Caryocar coriaceum Wittm.), harvested in January 2011 in the Araripe region, located in the southern Ceará state. The fruits were pulped in depulper stainless steel. The integral pulp obtained was packed in polyethylene bags sealed and frozen at $-20{ }^{\circ} \mathrm{C}$.

The pequi pulp presented moisture content of $80 \%$ ( $5{ }^{\circ} \mathrm{Brix}$ ), it was concentrated by a rotary evaporator at $60{ }^{\circ} \mathrm{C}$ under vacuum, yielding concentrated pequi pulps with different 
concentrations of total soluble solids $(6,8,10$ e 12 $\left.{ }^{0} \mathrm{Brix}\right)$, which correspond to the moisture contents of 70, 65, 60 and 55\%, respectively. Subsequently, pequi pulps were processed for determination of specific heat, thermal diffusivity and thermal conductivity.

\section{Thermophysical properties}

The determination of the specific heat of the pequi pulps with different contents of total soluble solids $\left(6,8,10\right.$ and $12{ }^{\circ}$ Brix) was made by the method of mixtures using the calorimeter (MOHSENIN, 1980). The calorimeter used was built with a vacuum bottle, inserted into a plastic pipe of $200 \mathrm{~mm}$ diameter. The space between the bulb and the plastic cylinder was filled with glass wool to ensure maximum thermal insulation. The closure of the inner is made with a rubber stopper with a hole in the center through which the stem of the thermocouple for measuring the internal temperature goes.

To calculate the specific heat of the sample was used the Equations 1 and 2, in which the first was used to determine the heat capacity of the calorimeter.

$\mathrm{C}_{1} \mathrm{~m}_{1}\left(\mathrm{~T}_{1}-\mathrm{T}_{3}\right)+\mathrm{C}_{\text {cal }}\left(\mathrm{T}_{1}-\mathrm{T}_{3}\right)=\mathrm{C}_{2} \mathrm{~m}_{2}\left(\mathrm{~T}_{3}-\mathrm{T}_{2}\right)$

where:

$\mathrm{C}_{1}$ and $\mathrm{C}_{2}$ - specific heat of water $\left(\mathrm{kJ} / \mathrm{kg}{ }^{\circ} \mathrm{C}\right)$

$\mathrm{m}_{1}$ - mass of water at room temperature $(\mathrm{g})$

$\mathrm{m}_{2}$ - mass of chilled water $(\mathrm{g})$

$\mathrm{T}_{1}$ - water temperature $30^{\circ} \mathrm{C}$

$\mathrm{T}_{2}$ - temperature of chilled water $15^{\circ} \mathrm{C}$

$\mathrm{T}_{3}$ - equilibrium temperature $\left({ }^{\circ} \mathrm{C}\right)$

$\left.{ }^{\circ} \mathrm{C}\right)$

$\mathrm{C}_{\mathrm{cal}}$ - heat capacity of the calorimeter $(\mathrm{kJ} / \mathrm{kg}$

It was used the Equation 2 to calculate the specific heat, at temperatures from 10 to $50{ }^{\circ} \mathrm{C}$ of the sample: $m_{p} C_{2}\left(\mathrm{~T}_{4}-\mathrm{T}_{\mathrm{E}}\right)=C_{1} m_{3}\left(\mathrm{~T}_{5}-\mathrm{T}_{3}\right)+\operatorname{Ccal}\left(\mathrm{T}_{5}-\mathrm{T}_{2}\right)(2)$ where:

$\mathrm{m}_{\mathrm{p}}$ - mass of the product $(\mathrm{g})$

$\mathrm{C}_{\mathrm{p}}$ - specific heat of the product $\left(\mathrm{kJ} / \mathrm{kg}{ }^{\circ} \mathrm{C}\right)$

$\mathrm{C}_{1}$ - specific heat of water $\left(\mathrm{kJ} / \mathrm{kg}{ }^{\circ} \mathrm{C}\right)$

$\mathrm{m}_{3}$ - sum of the masses $\mathrm{m}_{1}$ and $\mathrm{m}_{2}$

$\mathrm{T}_{4}$ - initial pulp temperature $\left({ }^{\circ} \mathrm{C}\right)$

$\mathrm{C}_{\text {cal }}$ - heat capacity of the calorimeter

$\mathrm{T}_{3}$ - equilibrium temperature $\left({ }^{\circ} \mathrm{C}\right)$

$\mathrm{T}_{5}$ - equilibrium temperature $\left({ }^{\circ} \mathrm{C}\right)$

The determination of the thermal diffusivity of the pequi pulps with different total soluble solids contents $\left(6,8,10\right.$ and $12{ }^{\circ}$ Brix) was determined using the method of Dickerson (1965), using a metal capsule plated brass, insulated at the ends and coupled with two thermocouples, one to check the internal temperature in the center of the capsule and the other on its surface in order to record the variations in the sample temperature. The capsule was filled with sample and immersed in the water bath with mechanical stirring. The thermal diffusivity was calculated according to Equation 3.

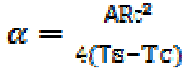

In which:

$\alpha$ - thermal diffusivity $\left(\mathrm{m}^{2} / \mathrm{s}\right)$

A - heating rate $\left({ }^{\circ} \mathrm{C} / \mathrm{s}\right)$

$\mathrm{R}_{\mathrm{c}}$ - cylinder radius/capsule $(\mathrm{m})$

$\mathrm{T}_{\mathrm{s}}$ - surface temperature of the radius $\mathrm{R}$ capsule $\left({ }^{\circ} \mathrm{C}\right)$

$\mathrm{T}_{\mathrm{C}}$ - temperature in the center of the sample $\left({ }^{\circ} \mathrm{C}\right)$

The theoretical thermal diffusivity of the pequi pulps were calculated using equations, as shown in Table 1 , at temperatures from 10 to $50{ }^{\circ} \mathrm{C}$.

Table 1. Theoretical equations of thermal diffusivity

\begin{tabular}{ccc}
\hline Product & Equation & Source \\
\hline $\begin{array}{c}\text { Food in } \\
\text { general }\end{array}$ & $\propto=(0,057363 \cdot \mathrm{Xw}+0,000288 \cdot \mathrm{T}) \cdot 10^{-6}$ & MARTENS (1980) \\
\hline $\begin{array}{c}\text { Food in } \\
\text { general }\end{array}$ & $\alpha=0,088 \cdot 10^{-6}+\left(\alpha w-0,088 \cdot 10^{-6} \cdot \mathrm{Xw}\right)$ & RIEDEL (1969) \\
\hline Orange juice & $\alpha=7,9683 \cdot 10^{-9}+5,9839 \cdot 10^{-8} \cdot \mathrm{Xw}+0,02510 \cdot 10^{-9} \cdot \mathrm{T}$ & TELIS ROMERO (1998) \\
\hline Lulo juice & $a=8,29 \cdot 10^{-8}-5,27 \cdot 10^{-8} \cdot \mathrm{Xw}+2,76 \cdot 10^{-10}$ & $\begin{array}{c}\text { GIRALDO-GÓMEZ et al. } \\
(2010)\end{array}$ \\
\hline
\end{tabular}

Where: $\alpha$ - thermal diffusivity $\left(\mathrm{m}^{2} / \mathrm{s}\right) ; \mathrm{X}_{\mathrm{w}-}$ mass fraction of water (dimensionless); $\alpha_{\mathrm{w}}$ - water diffusivity $\left(20{ }^{\circ} \mathrm{C}\right) ; \mathrm{T}-$ temperature $\left({ }^{\circ} \mathrm{C}\right)$

The thermal conductivity (k) of pequi pulps with different amounts of total soluble solids (5, 6,
8,10 and $12{ }^{\circ}$ Brix) at temperatures of 10 to $50{ }^{\circ} \mathrm{C}$ were determined using a thermal sensor, KD2 
(Decagon Inc., KD2 model). The thermal conductivity was expressed in $\mathrm{W} \mathrm{m}^{-1}{ }^{\circ} \mathrm{C}^{-1}$.
The equations that are in Table 2 were used to estimate the thermal conductivity of the pulp.

Table 2. Equations for calculation of theoretical thermal conductivity, at temperatures from 10 to $50{ }^{\circ} \mathrm{C}$.

\begin{tabular}{ccc}
\hline Product & Equation & Source \\
\hline \multirow{2}{*}{ Fruit juice } & $\mathrm{K}=0,140+0,42 . \mathrm{Xw}$ & KOLAROV \& \\
& & GROMOV (1973) \\
\hline
\end{tabular}

$$
\text { Apple juice } \mathrm{K}=0,27928-3,5722 \cdot 10^{-3} \cdot \mathrm{B}+1,1357 \cdot 10^{-2} \cdot \mathrm{T} \quad \text { CONSTENLA (1989) }
$$

\begin{tabular}{ccc}
$\begin{array}{c}\text { Orange } \\
\text { juice }\end{array}$ & $\mathrm{K}=0,0797+0.538 \mathrm{Xw}+0,000580 . \mathrm{T}$ & $\begin{array}{c}\text { TELIS-ROMERO et al. } \\
(1998)\end{array}$ \\
\hline
\end{tabular}

Where: $\mathrm{K}$ - thermal conductivity $\left(\mathrm{W} / \mathrm{m}{ }^{\circ} \mathrm{C}\right) ; \mathrm{Xw}$ - mass fraction of water (dimensionless); $\mathrm{T}$ - temperature $\left({ }^{\circ} \mathrm{C}\right) ; \mathrm{B}-{ }^{\circ} \mathrm{Brix}$.

The specific heat data were evaluated by means of factorial $4 \times 5 \times 3$, (total soluble solids, temperature and replications) using the program ASSISTAT version 7.6.

For statistical analysis of thermal diffusivity was used completely randomized design (CRD) program ASSISTAT applied in version 7.6, with a comparison of means using the Tukey test. For thermal conductivity was conducted by factorial ( $4 \times 5 \times 3)$, which corresponds to 4 soluble solids, 5 temperatures and 3 replications.

The determination of the percentage error (Equation 4) was used to evaluate the experimental and theoretical data of thermophysical properties, among them the thermal diffusivity and thermal conductivity equations.

$E=\left(\frac{V_{c a i}-V_{s x p}}{V_{\mathrm{sxp}}}\right) \times 100$

where:

$\mathrm{E}$ - percentage error $(\%)$

Vexp - experimental value

Vcal - calculated value

\section{RESULTS AND DISCUSSION}

\section{Specific heat}

In Table 3 it can be seen that with increasing temperature in the pequi pulp, there was a tendency of increase of the specific heat. The specific heat decreased with an increase of total soluble solids. It was observed that the minimum specific heat was $2.20 \mathrm{~kJ} / \mathrm{kg}{ }^{\circ} \mathrm{C}$ and the maximum specific heat of $3.45 \mathrm{~kJ} / \mathrm{kg}{ }^{\circ} \mathrm{C}$. The specific heat of fruit pulp can vary according to their chemical and physico-chemical composition, in addition to direct influence on determination of the amount of energy being added or removed in process of heating and cooling (ARAÚJO et al., 2004). To Souza et al.
(2011), the higher the moisture content of the pulp will be higher specific heat, but the effect of the total solids is less important due to the various components (fat, protein, sugars and ash) exert a smaller influence as compared with water.

Note that there was no significant difference between the means of the specific heat at the temperature of $10{ }^{\circ} \mathrm{C}$ between the pulp in different levels of total soluble solids.

At $20{ }^{\circ} \mathrm{C}$ there was no significant difference between the mean specific heat of the pulps with 8 , 10 and $12{ }^{\circ} \mathrm{Brix}$; at $30^{\circ} \mathrm{C}$ the specific heat of the pequi pulps with 6,8 and $10^{\circ} \mathrm{Brix}$ did not differ statistically; at $40^{\circ} \mathrm{C}$ the average specific heat of pequi pulp with 8 and $10^{\circ}$ Brix were statistically the same; and at $50{ }^{\circ} \mathrm{C}$ the means with pequi pulp with 6,8 and $10^{\circ}$ Brix were also statistically similar.

Note in the temperature of $10{ }^{\circ} \mathrm{C}$ that the mean specific heat between the pulp with different total soluble solids contents were very close; an increase in ${ }^{\circ}$ Brix remained the specific heat steady between pulps with different soluble solids, at $20^{\circ} \mathrm{C}$ the specific heat of the pulp at $6{ }^{\circ}$ Brix value presented farther from the other pulp and pulp of medium 8,10 and 12 Brix were similar; and a lower average value than the other pulp; at $30{ }^{\circ} \mathrm{C}$ the specific heat of the pequi pulp 6,8 and $10{ }^{\circ}$ Brix were similar and the pulp with $12{ }^{\circ}$ Brix showed lower mean and different value from other pulp; at $40{ }^{\circ} \mathrm{C}$ the means of the specific heat of pequi pulp with 8 and $10^{\circ}$ Brix were similar; pulps at 6 and 12 ${ }^{\circ}$ Brix showed the highest and lowest value, respectively; and at $50{ }^{\circ} \mathrm{C}$ the medium of the pequi pulps with 6,8 and $10^{\circ}$ Brix were also similar; and pulp with $12{ }^{\circ}$ Brix presenting the lowest value and different from the other samples. 
Table 3. Specific heat $\left(\mathrm{kJ} / \mathrm{kg}{ }^{\circ} \mathrm{C}\right)$ of the pequi pulps with temperature and different levels of total soluble solids.

\begin{tabular}{ccccc}
\hline Temperature & \multicolumn{4}{c}{ Total soluble solids $\left({ }^{\circ}\right.$ Brix $)$} \\
\cline { 2 - 5 }$\left({ }^{\circ}\right)$ & $\mathbf{6}$ & $\mathbf{8}$ & $\mathbf{1 0}$ & $\mathbf{1 2}$ \\
\cline { 2 - 5 } 10 & $2.24 \mathrm{eA}$ & $2.22 \mathrm{eA}$ & $2.20 \mathrm{eA}$ & $2.21 \mathrm{dA}$ \\
20 & $2.59 \mathrm{dA}$ & $2.54 \mathrm{~dB}$ & $2.52 \mathrm{~dB}$ & $2.51 \mathrm{cB}$ \\
30 & $2.98 \mathrm{cA}$ & $2.93 \mathrm{cA}$ & $2.97 \mathrm{cA}$ & $2.84 \mathrm{bB}$ \\
40 & $3.37 \mathrm{bA}$ & $3.29 \mathrm{bB}$ & $3.29 \mathrm{bB}$ & $3.15 \mathrm{aC}$ \\
50 & $3.45 \mathrm{aA}$ & $3.42 \mathrm{aA}$ & $3.42 \mathrm{aA}$ & $3.17 \mathrm{aB}$ \\
\hline
\end{tabular}

Means followed by the same letter in columns and rows in the capital, do not differ by Tukey test at 5\% probability.

For the pequi pulp with total soluble solids of $6{ }^{\circ}$ Brix $\left(70 \%\right.$ moisture content) and $12{ }^{\circ}$ Brix (55\% moisture content) results were below those found by Sousa et al. (2010), for umbu pulp, which ranged from 3.66 to $4.18 \mathrm{~kJ} / \mathrm{kg}{ }^{\circ} \mathrm{C}$ for moisture content from 70 to $95 \%$ and at different temperatures $(5,15,25,35,45,55,65,75$ and 85 $\left.{ }^{\circ} \mathrm{C}\right)$. Approximate results were found by Muniz et al. (2006) when studying the specific heat of bacuri pulp depending on the concentration of soluble solids (5-20 ${ }^{\circ}$ Brix), which varied between 2.98 and $3.61 \mathrm{~kJ} / \mathrm{kg}{ }^{\circ} \mathrm{C}$.

Results similar to those found in pequi pulp were checked by Souza et al. (2011), and found maximum average experimental values for minimum specific heat of $2.70 \mathrm{~kJ} / \mathrm{kg}{ }^{\circ} \mathrm{C}$ and 3.92 $\mathrm{kJ} / \mathrm{kg}{ }^{\circ} \mathrm{C}$ to jackfruit pulp with moisture contents of $65-95 \%$. The values obtained by Araújo et al. (2004) for specific experimental heats of cupuassu pulp with a $9{ }^{\circ}$ Brix and sieved, were $3.24 \mathrm{~kJ} / \mathrm{kg}{ }^{\circ} \mathrm{C}, 3,71$ $\mathrm{kJ} / \mathrm{kg}{ }^{\circ} \mathrm{C}$ and $3.18 \mathrm{~kJ} / \mathrm{kg}{ }^{\circ} \mathrm{C}$, respectively, close to the pequi pulps with different contents of total soluble solids and at elevated temperatures (40 and $50{ }^{\circ} \mathrm{C}$ ).

Bon et al. (2010) found that the specific heat of mango pulp at temperatures of 20,40,60 and 80 ${ }^{\circ} \mathrm{C}$ and moisture content between 50 and $90 \%$ was between 2.738 to $4.093 \mathrm{~kJ} / \mathrm{kg}{ }^{\circ} \mathrm{C}$; where the values of the specific heat of pequi pulp with moisture content of $55 \%$ (12 $\left.{ }^{\circ} \mathrm{Brix}\right)$ to $70 \%$ (6 $\left.{ }^{\circ} \mathrm{Brix}\right)$ were within this rating ( 2.20 to $3.45 \mathrm{~kJ} / \mathrm{kg}{ }^{\circ} \mathrm{C}$ ).

Muramatsu et al. (2010) measured the thermophysical properties of three kinds of juice (grape, orange and cucumber), at temperatures ranging from 10 to $50{ }^{\circ} \mathrm{C}$ and soluble solids concentrations of 10 to $50{ }^{\circ} \mathrm{Brix}$, and found that the values of the specific heat ranged from 2.6 to 4.1 $\mathrm{kJ} / \mathrm{kg}{ }^{\circ} \mathrm{C}$, observed in the pequi pulps values close to those.

\section{Thermal diffusivity}

Table 4 presents the values of thermal diffusivity of pequi pulp due to total soluble solids content. It is observed that the diffusivity tends to decrease with to increase total soluble solids content. All average values of thermal diffusivity were statistically different according to Tukey's test at the 5\% probability level. It is observed that the thermal diffusivity decreased with the increase of soluble solids. This behavior was expected since the thermal diffusivity measures the ability of the sample (pulp) to conduct energy, varies according to the composition there of, and the lower the concentration of samples the greater its ability to conduct energy.

Table 4. Thermal diffusivity of pequi pulps with different levels of soluble solids.

Total soluble solids $\left({ }^{\circ} \mathrm{Brix}\right)$

Thermal diffusivity $\left(\mathrm{m}^{2} \mathbf{s}^{-1}\right)$
Means followed by the same letter do not differ by Tukey test at 5
Corrêa et al. (2008) studied the thermal
diffusivity of papaya pulp depending on of
maturation, noting that after ripening the fruits
soften by cellular degradation and an increase in
permeability occurs, consequently there was an
increase of total soluble solids content of fruits and
decreased of thermal diffusivity.

10

12 
cashew juice in concentrations of 5 to $25^{\circ}$ Brix, observing a variation in the diffusivity of $1.34 \times 10^{-7}$ to $1.44 \times 10^{-7} \mathrm{~m}^{2} \mathrm{~s}^{-1}$, with the results found on the pequi pulps with levels of total soluble solids 8-12 ${ }^{\circ}$ Brix lower. Giraldo-Gomez et al. (2010) evaluated the thermophysical properties of lulo juice with moisture content of $55-90 \%$ and found values of thermal diffusivity of $0.95 \times 10^{-7}$ to $1.33 \times 10^{-7} \mathrm{~m}^{2} \mathrm{~s}^{-}$ ${ }^{1}$, with the diffusivity of pequi pulp within this rating.

In the Table 5 was find the thermal diffusivity experimentally measured and theoretical values. It is observed that the theoretical values of thermal diffusivity calculated were equal to or lower than the experimental values. The equations that best estimated the experimental data was that of Telis-Romero (1998) and Riedel (1969), which showed values close to the experimental errors with percentages less than 4\%; the other equations resulted in errors between 2.50 and $9.13 \%$; in all samples the biggest mistakes ever occurred in samples with higher total soluble solids, decreasing with a decrease of total soluble solids.

Table 5. Experimental and theoretical values of the thermal diffusivities obtained through equations and percentage errors

\begin{tabular}{ccccc}
\hline Equations & \multicolumn{4}{c}{ Thermal diffusivities $\left(\mathbf{m}^{\mathbf{2}} \mathbf{s}^{-1}\right)$} \\
& $\mathrm{X}_{\mathrm{w}}$ & Experimental & Theoretical & Erro (\%) \\
\cline { 2 - 5 } RIEDEL (1969) & 0.55 & $1.23 \times 10^{-7}$ & $1.19 \times 10^{-7}$ & 3.23 \\
& 0.60 & $1.26 \times 10^{-7}$ & $1.23 \times 10^{-7}$ & 3.27 \\
& 0.65 & $1.29 \times 10^{-7}$ & $1.26 \times 10^{-7}$ & 3.06 \\
& 0.70 & $1.32 \times 10^{-7}$ & $1.28 \times 10^{-7}$ & 2.86 \\
\cline { 2 - 5 } & $\mathrm{X}_{\mathrm{w}}$ & Experimental & Theoretical & Erro (\%) \\
\hline & 0.55 & $1.23 \times 10^{-7}$ & $1.16 \times 10^{-7}$ & 5.96 \\
MARTENS (1980) & 0.60 & $1.26 \times 10^{-7}$ & $1.19 \times 10^{-7}$ & 5.92 \\
& 0.65 & $1.29 \times 10^{-7}$ & $1.22 \times 10^{-7}$ & 5.65 \\
TELIS-ROMERO (1998) & 0.70 & $1.32 \times 10^{-7}$ & $1.25 \times 10^{-7}$ & 5.38 \\
\cline { 2 - 5 } & $\mathrm{X}_{\mathrm{w}}$ & Experimental & Theoretical & Erro (\%) \\
\hline & 0.55 & $1.23 \times 10^{-7}$ & $1.18 \times 10^{-7}$ & 3.62 \\
& 0.60 & $1.26 \times 10^{-7}$ & $1.22 \times 10^{-7}$ & 3.54 \\
& 0.65 & $1.29 \times 10^{-7}$ & $1.25 \times 10^{-7}$ & 3.21 \\
GIRALDO-GÓMEZ et al. & 0.70 & $1.32 \times 10^{-7}$ & $1.28 \times 10^{-7}$ & 2.90 \\
\hline (2010) & $\mathrm{X}_{\mathrm{w}}$ & Experimental & Theoretical & Erro (\%) \\
\cline { 2 - 5 } & 0.55 & $1.23 \times 10^{-7}$ & $1.12 \times 10^{-7}$ & 9.06 \\
& 0.60 & $1.26 \times 10^{-7}$ & $1.15 \times 10^{-7}$ & 9.13 \\
& 0.65 & $1.29 \times 10^{-7}$ & $1.17 \times 10^{-7}$ & 8.97 \\
& 0.70 & $1.32 \times 10^{-7}$ & $1.20 \times 10^{-7}$ & 8.81 \\
\hline
\end{tabular}

$* \overline{\mathrm{X}_{\mathrm{W}}}$ - moisture content (decimal), then the moisture content corresponds to the following soluble solids: 0.55 (12 $\left.{ }^{\circ} \mathrm{Brix}\right) ; 0.60$ (10 $\left.{ }^{\circ} \mathrm{Brix}\right)$; 0.65 ( $8{ }^{\circ}$ Brix $)$ and $0.70\left(6^{\circ}\right.$ Brix $)$.

\section{Thermal conductivity}

Table 6 has the thermal conductivity of pequi pulp with soluble solids between $6{ }^{\circ}$ Brix (70\% moisture content) to $12{ }^{\circ} \mathrm{Brix}(55 \%$ moisture content), at temperatures of 10,20,30,40 and 50 ${ }^{\circ} \mathrm{C}$. It is observed that the thermal conductivity showed values ranging from 0.3650 to $0.4723 \mathrm{~W} / \mathrm{m}$ ${ }^{\circ} \mathrm{C}$.

It is observed that in the temperatures of 10 , 20, 30, 40 and $50{ }^{\circ} \mathrm{C}$ the samples with $12{ }^{\circ} \mathrm{Brix}$ had lower thermal conductivity than the samples with 6 ${ }^{\circ}$ Brix. Based on the results it was evident that the thermal conductivity showed no clear trend with increasing temperature in the pulps studied. GiraldoGómez et al. (2010) found, when determining the thermal conductivity of the lulo juice (Solanum quitoense Lam) with moisture content ranging between $0.50-0.90 \mathrm{~kg} / \mathrm{kg}$ and temperatures from 4 to $78.6{ }^{\circ} \mathrm{C}$, the results of thermal conductivity found showed a tendency to increase with rise in temperature, but for pequi pulps at temperatures 10$50{ }^{\circ} \mathrm{C}$ was not a trend. Villa-Velez et al. (2012) concluded, evaluating the thermal conductivity of the uvaia juice, there was an increase in conductivity with increasing temperature between 0 and $40{ }^{\circ} \mathrm{C}$, pequi pulp was not observed this trend.

Higher thermal conductivity values of pequi pulps were found by Muramatsu et al. (2010), when measuring thermophysical properties of grape and orange juice, at temperatures ranging from 10 to 50 ${ }^{\circ} \mathrm{C}$ and total solids concentration of 10 to $50{ }^{\circ} \mathrm{Brix}$, with values of thermal conductivity ranging between 
0.42 and $0.62 \mathrm{~W} / \mathrm{m}{ }^{\circ} \mathrm{C}$ for the grape juice and 0.46 to $0.61 \mathrm{~W} / \mathrm{m}{ }^{\circ} \mathrm{C}$ for orange juice, and the thermal conductivity increasing linearly with the increase of temperature and decreases with the increase of concentration. Cabral et al. (2007) observed for the blackberry juice with soluble solids of 9.4 and 58.4 ${ }^{\circ}$ Brix and at temperatures of between 0.5 and 80.8
${ }^{\circ} \mathrm{C}$, the thermal conductivity ranged between 0.389 and $0.652 \mathrm{~W} / \mathrm{m}{ }^{\circ} \mathrm{C}$, the thermal conductivity of pequi decreases with the increase in total soluble solids between the sample 6 and $12{ }^{\circ}$ Brix, with a thermal conductivity values within the range of results for blackberry.

Table 6. Thermal conductivity of pequi pulp $\left(\mathrm{W} / \mathrm{m}{ }^{\circ} \mathrm{C}\right)$ with different total soluble solids contents and different temperature.

\begin{tabular}{ccccc}
\hline Temperature & \multicolumn{4}{c}{ Total soluble solids $\left({ }^{\mathbf{0}} \mathbf{B r i x}\right)$} \\
\cline { 2 - 5 } $\left.\mathbf{(}^{\mathbf{C}} \mathbf{C}\right)$ & $\mathbf{6}$ & $\mathbf{8}$ & $\mathbf{1 0}$ & $\mathbf{1 2}$ \\
\hline 10 & $0.4253 \mathrm{bA}$ & $0.4380 \mathrm{aA}$ & $0.4333 \mathrm{bA}$ & $0.3780 \mathrm{abB}$ \\
20 & $0.4723 \mathrm{aA}$ & $0.4127 \mathrm{bB}$ & $0.4050 \mathrm{cB}$ & $0.3910 \mathrm{aB}$ \\
30 & $0.4307 \mathrm{bA}$ & $0.4077 \mathrm{bB}$ & $0.4217 \mathrm{bcAB}$ & $0.4010 \mathrm{aB}$ \\
40 & $0.4390 \mathrm{bA}$ & $0.4483 \mathrm{aA}$ & $0.4143 \mathrm{bcB}$ & $0.3910 \mathrm{aC}$ \\
50 & $0.4280 \mathrm{bB}$ & $0.3983 \mathrm{bC}$ & $0.4620 \mathrm{aA}$ & $0.3650 \mathrm{bD}$ \\
\hline
\end{tabular}

Means followed by the same letter do not differ by Tukey test at $5 \%$ probability

Tables 7-10 are theoretical thermal conductivities of pequi pulp with different moisture contents, calculated according to the equations of Kolarov e Gromov (1973) and Telis-Romero et al. (1998) with their respective percentage errors (\%). In Telis-Romero equation is an increase in thermal conductivity with the increasing of moisture content and temperature where the values remained between 0.3736 and $0.4754 \mathrm{~W} / \mathrm{m}^{\circ} \mathrm{C}$.
Table 7 has theoretical values thermal conductivity of pequi pulp with $6{ }^{\circ}$ Brix corresponds to $70 \%$ of moisture content, calculated with different equations and percentages errors. The equations of Kolarov \& Gromov and Telis-Romero can be used accurately to predict the thermal conductivity of pequi pulp with moisture content, for the temperatures studied, since they showed percentage errors from 0.70 to $8.05 \%$.

Table 7. Theoretical values of thermal conductivity for pequi pulp with $6^{\circ}$ Brix and percentage errors

\begin{tabular}{cccc}
\hline Equation & Temp. $\left({ }^{\mathbf{0}} \mathbf{C}\right)$ & $\begin{array}{c}\text { Theoretical thermal conductivity } \\
\left(\mathbf{W} / \mathbf{m}{ }^{\circ} \mathbf{C}\right)\end{array}$ & Erro (\%) \\
\hline & 10 & 0.4340 & 2.12 \\
KOLAROV \& & 20 & 0.4340 & 8.05 \\
GROMOV (1973) & 30 & 0.4340 & 0.70 \\
& 40 & 0.4340 & 1.14 \\
& 50 & 0.4340 & 1.40 \\
TELIS-ROMERO et al. & 10 & 0.4522 & 6.39 \\
(1998) & 20 & 0.4580 & 4.20 \\
& 40 & 0.4638 & 4.91 \\
& 50 & 0.4696 & 3.00 \\
\hline
\end{tabular}

In Table 8 it was find the theoretical values of thermal conductivity for pequi pulp with $8^{\circ}$ Brix, it is observed that the minimum percentage error was $0.24 \%$ and maximum $7.03 \%$. It is suggested to use the equations of Kolarov \& Gromov and TelisRomero to estimate thermal conductivity of the pequi pulp with content of total soluble solids of 8 ${ }^{\circ}$ Brix, because of referral percentage errors less than $10 \%$ at all temperatures studied.
Table 9 has the theoretical values of thermal conductivity for pequi pulp with $10^{\circ}$ Brix, calculated with the equations Kolarov \& Gromov (1973) and Telis-Romero et al. (1998). It is found that the percentage error for equations mentioned exceeds $10 \%$ at temperature of $50{ }^{\circ} \mathrm{C}$, with values of 15.15 and $13.47 \%$, respectively. In this light it is clear that, for other temperatures $\left(10,20,30\right.$ and $\left.40{ }^{\circ} \mathrm{C}\right)$, it can used the equations tested to estimate the thermal conductivity aiming pequi pulp with $10^{\circ} \mathrm{Brix}$. 
Table 8. Theoretical values of thermal conductivity for pequi pulp with $8^{\circ}$ Brix and percentage errors

\begin{tabular}{cccc}
\hline Equation & Temp. $\left({ }^{\mathbf{0}} \mathbf{C}\right)$ & $\begin{array}{c}\text { Theoretical thermal conductivity } \\
\left(\mathbf{W} / \mathbf{m}{ }^{\circ} \mathbf{C}\right)\end{array}$ & Erro (\%) \\
\hline \multirow{2}{*}{ KOLAROV \& GROMOV } & 10 & 0.4130 & 5.71 \\
$(1973)$ & 20 & 0.4130 & 0.24 \\
& 30 & 0.4130 & 1.23 \\
& 40 & 0.4130 & 7.81 \\
TELIS-ROMERO et al. & 50 & 0.4130 & 3.77 \\
(1998) & 10 & 0.4260 & 2.75 \\
\hline & 30 & 0.4318 & 3.39 \\
& 40 & 0.4376 & 4.40 \\
& 50 & 0.4434 & 4.92 \\
\hline
\end{tabular}

Table 9. Theoretical values of thermal conductivity for pequi pulp with $10^{\circ} \mathrm{Brix}$ and percentage error

\begin{tabular}{cccc}
\hline Equation & Temp. $\left({ }^{\mathbf{0}} \mathbf{C}\right)$ & $\begin{array}{c}\text { Theoretical thermal conductivity } \\
\left(\mathbf{W} / \mathbf{m}{ }^{\circ} \mathbf{C}\right)\end{array}$ & Erro (\%) \\
\hline \multirow{3}{*}{ KOLAROV \& } & 10 & 0.3920 & 9.47 \\
GROMOV (1973) & 20 & 0.3920 & 3.21 \\
& 30 & 0.3920 & 7.11 \\
& 40 & 0.3920 & 6.00 \\
TELIS-ROMERO et al. & 50 & 0.3920 & 15.15 \\
\hline & 10 & 0.3998 & 7.67 \\
& 30 & 0.4056 & 1.29 \\
& 40 & 0.4114 & 5.27 \\
& 50 & 0.4172 & 4.13 \\
\end{tabular}

In pequi pulp with soluble solids contents with $12{ }^{\circ}$ Brix (Table 10) the percentage errors were between 0.0 and $7.48 \%$, meaning that for the temperatures studied, the Kolarov \& Gromov (1973) and Telis-Romero et al. (1998) equations can be used to predict this thermophysics for pequi pulp with this moisture content, due to have presented lower percentage error of $10 \%$, which are recommended and tested to estimate the thermal conductivity for pequi pulp of $12{ }^{\circ}$ Brix equivalent having $55 \%$ moisture content.

Table 10. Theoretical values of thermal conductivity for pequi pulp with $12^{\circ}$ Brix and percentage error.

\begin{tabular}{cccc}
\hline Equation & Temp. $\left({ }^{\mathbf{0}} \mathbf{C}\right)$ & $\begin{array}{c}\text { Theoretical thermal conductivity } \\
\left(\mathbf{W} / \mathbf{m}^{\circ} \mathbf{C}\right)\end{array}$ & Erro (\%) \\
\hline \multirow{2}{*}{ KOLAROV \& } & 10 & 0.3710 & 1.85 \\
GROMOV (1973) & 20 & 0.3710 & 0.00 \\
& 30 & 0.3710 & 7.48 \\
& 40 & 0.3710 & 5.12 \\
TELIS-ROMERO et al. & 50 & 0.3710 & 1.64 \\
(1998) & 10 & 0.3736 & 1.17 \\
& 30 & 0.3794 & 0.70 \\
& 40 & 0.3852 & 6.84 \\
& 50 & 0.3910 & 4.45 \\
\end{tabular}

\section{CONCLUSIONS}

The specific heat tended to increase with the increase of temperature for all samples and the increase of soluble solids pequi pulps showed a tendency to decrease the specific heat.

The thermal diffusivity of the pequi pulp decreases with increasing the soluble solids content. 
The Riedel, Martens, Telis-Romero and Giraldo-Gómez equations can be used to estimate the thermal diffusivity of pequi pulp with the Riedel equation showing smaller errors.
The thermal conductivity did not show a definite trend with the increase temperature in the pulps studied.

RESUMO: O fruto do pequi (Caryocar coriaceum Wittm) possui um grande interesse econômico, no que se refere ao uso de seus frutos na culinária como fonte de vitaminas e na extração de óleos para a fabricação de cosméticos. Todavia, são desconhecidos estudos voltados para as propriedades termofísicas (calor específico, difusividade térmica e condutividade térmica), nas quais são propriedades de suma importância para que a polpa seja beneficiada a nível industrial. O trabalho em questão teve como objetivo estudar as propriedades físicas da polpa de pequi com teores de sólidos solúveis totais de $6,8,10$ e $12{ }^{\circ}$ Brix. As propriedades físicas estudadas foram: calor específico, difusividade térmica e condutividade térmica. $\mathrm{O}$ calor específico das polpas foi realizado por meio do calorímetro de mistura, a difusividade térmica utilizando-se o método do cilindro de Dickerson e a condutividade térmica no equipamento KD-2. Portanto, constatou-se que o calor específico apresentou tendência de aumento com o aumento da temperatura e do teor de sólidos solúveis totais das polpas. A difusividade térmica da polpa de pequi diminui com o aumento dos sólidos solúveis totais, a condutividade térmica das polpas não apresentou uma tendência definida com o aumento da temperatura nas polpas estudadas.

PALAVRAS-CHAVE: Caryocar coriaceum Wittm. Calor específico. Condutividade térmica. Difusividade térmica.

\section{REFERENCES}

ALVES, C. C. O.; RESENDE, J. V.; PRADO, M. E. T.; CRUVINEL, R. S. R. The effects of added sugars and alcohols on the induction of crystallization and the stability of the freeze-dried peki (Caryocar brasiliense Camb.) fruit pulps. LWT - Food Science and Technology, Geórgia, v. 43, n. 6, p. 934-941, 2010.

ARAÚJO, J. L.; QUEIROZ, A. J. M.; FIGUEIREDO, R. M. F. Propriedades termofísicas da polpa do cupuaçu com diferentes teores de sólidos. Ciência Agrotecnologia, Lavras, v. 28, n. 1, p. 126-134, 2004.

AZOUBEL, P. M.; CIPRIANI, D. C.; EL-AOUAR, Â. A.; ANTONIO,G. C.; MURR,F. E. X. Effect of concentration on the physical properties of cashew juice. Journal of Food Engineering, California, v. 66, n. 4, p. 413-417, 2005. http://dx.doi.org/10.1016/j.jfoodeng.2004.04.008

BON, J.; VÁQUIRO, H.; BENEDITO, J.; TELIS-ROMERO, J. Thermophysical properties of mango pulp (Mangifera indica L. cv. Tommy Atkins). Journal of Food Engineering, California v. 97, n. 4, p. 563-568, 2010. http://dx.doi.org/10.1016/j.jfoodeng.2009.12.001

CABRAL, R. A. F.; ORREGO-ALZATE, C. E.; GABAS, A. L., TELIS-ROMERO, J. Propriedades reológicas e termofísicas de suco de amora. Ciência e Tecnologia de Alimentos, Campinas, v. 27, n. 3, p. 589-596, 2007. http://dx.doi.org/10.1590/S0101-20612007000300025

CORREAA, S. F.; SOUZA, M. S.; PEREIRA, T.; ALVES, G. V. L.; OLIVEIRA, J. G.; SILVA, M. G.; VARGAS, H. Determination of thermal diffusivity in papaya pulp as a function of maturation stage. Revista Brasileira de Fruticultura, Jaboticabal, v. 30, n. 3, p. 611-615, 2008.

CONSTENLA, D. T.; LOZANO, J. E.; CRAPISTE, G. H. Thermophysical properties of clarified apple juice as a function of concentration and temperature. Journal of Food Science, New York, v. 54, n. 3, p. 663-668, 1989. http://dx.doi.org/10.1111/j.1365-2621.1989.tb04677.x

DICKERSON, R. W. 1965. An apparatus for the measurement of thermal diffusivity of foods. Food Technology, Chicago, v. 19, n. 5, p. 198-204,1965. 
GIRALDO-GÓMEZ, G. I.; GABAS, A. L.; TELIS, V. R. N.; TELIS-ROMERO, J. Propiedades termofísicas del jugo concentrado de lulo a temperaturas por encima del punto de congelación. Ciência e Tecnologia de Alimentos, Campinas, v. 30, supl. 1, p. 90-95, 2010. http://dx.doi.org/10.1590/S0101-20612010000500015

GONÇALVES, G. A. S.; VILAS BOAS, E. V. B.; RESENDE, J. V.; MACHADO, A. L.; VILAS BOAS, B. M. Qualidade dos frutos do pequizeiro submetidos a diferentes tempos de cozimento. Ciência e Agrotecnologia, Lavras, v. 35, n. 2, p. 377-385, 2011.

KOLAROV, K. M., GROMOV, M. A. Universal equation for calculation of thermal condutivity of fruit and vegetable juices and syrups. Khranitelna Promishhlenost, v. 20, n. 10, p. 22-32, 1973.

MARTENS, T. Mathematical model of heat processing in flat containers. 1.ed. Catholic University Louvain, Leunen: Katholeike University, 1980. 207p.

MERCALI, G. D.; SARKIS, J. R.; JAESCHKE, D. P.; TESSARO, I. C.; MARCZA, K. L. D. F. Physical properties of acerola and blueberry pulps. Journal of Food Engineering, California, v. 106, n. 4, p. 283-289, 2011. http://dx.doi.org/10.1016/j.jfoodeng.2011.05.010

MOHSENIN, N. N. Thermal properties of foods and agricultural materials. 1.ed.Gordon and Breach Science Publishers, New York, 1980, 407p.

MOURA, S. C. S. R.; FRANÇA, V. C. L.; LEAL, A. M. C. B. Propriedades termofísicas de soluções-modelo similares a sucos: parte II. Ciência e Tecnologia de Alimentos, Campinas, v. 25, n. 3, p. 454-459, 2005. http://dx.doi.org/10.1590/S0101-20612005000300011

MUNIZ, M. B.; QUEIROZ, A. J. M.; FIGUEIREDO, R. M. F.; DUARTE, M. E. M. Caracterização termofísica de polpas de bacuri. Ciência e Tecnologia de Alimentos, Campinas, v. 26, n. 2, p. 360-368, 2006.

http://dx.doi.org/10.1590/S0101-20612006000200019

MURAMATSU, Y.; SAKAGUCHI, E.; ORIKASA, T.; TAGAWA, A. Simultaneous estimation of the thermophysical properties of three kinds of fruit juices based on the measured result by a transient heat flow probe method. Journal of Food Engineering, California, v. 96, n. 4, p. 607-613, 2010.

http://dx.doi.org/10.1016/j.jfoodeng.2009.09.008

RIEDEL, L. Measurements of thermal difusivity on foods tuffs rich in water. Kqltetechnik-Klimatisieuring, v. 21 , n. 11 , p. $315-316.1969$.

SOUZA, M. A.; BONOMO, R. C. F.; FONTAN, R. C. I.; MINIM, L. A.; COIMBRA, J. S. R.; BONOMO, P. Thermophysical properties of umbu pulp. Brazilian Journal of Food Technology, Campinas, v. 13, n. 3, p. 219-225, 2010. http://dx.doi.org/10.4260/BJFT2010130300029

SOUZA, E. C.; VILAS BOAS, E. V. B.; VILAS BOAS, B. M.; RODRIGUES, L. J.; PAULA, N. R. F. Qualidade e vida útil de pequi minimamente processado armazenado sob atmosfera modificada. Revista Ciência e Agrotecnologia, Lavras, v. 31, n. 6, p. 1811-1817, 2007.

SOUZA, M.; BONOMO, C. F.; FONTAN, R. C. I.; MINIM, L. A.; COIMBRA, J. S. R. Thermophysical properties of jackfruit pulp affected by changes in moisture content and temperature. Journal of Food Process Engineering, Texas, v. 34, n. 3, p. 580-592, 2011. http://dx.doi.org/10.1111/j.1745-4530.2009.00402.x

VILLA-VELEZ, H. A.; TELIS-ROMERO, J.; HIGUITA, D. M. C.; TELIS, V. R. N. Effect of maltodextrin on the freezing point and thermal conductivity of uvaia pulp (Eugenia piriformis Cambess). Ciência $\mathbf{e}$

Agrotecnologia, Lavras, v. 36, n. 1, p. 78-85, 2012. 